\title{
A New Genus of the Order Actinomycetales, Spirilliplanes gen. nov., with Description of Spirilliplanes yamanashiensis sp. nov.
}

\author{
TOMOHIKO TAMURA, ${ }^{1 *}$ MASAYUKI HAYAKAWA, ${ }^{2}$ AND KAZUNORI HATANO ${ }^{1}$ \\ Institute for Fermentation, Osaka, Yodogawa-ku, Osaka 532, ${ }^{1}$ and Department of Applied Chemistry and \\ Biotechnology, Faculty of Engineering, Yamanashi University, Kofu $400,{ }^{2}$ Japan
}

\begin{abstract}
Actinomycete strain YU127-1 ${ }^{\mathrm{T}}(\mathrm{T}=$ type strain), which produces zoospores, was isolated from a soil sample. The aerial mycelium of this organism at maturity forms short chains of spores. The hyphae form coils, and sporangia are not observed. Strain YU127-1 ${ }^{\mathrm{T}}$ contains glutamic acid, glucosamine, glycine, alanine, and mesodiaminopimelic acid in its cell wall (wall chemotype II), 3-O-methylmannose, mannose, xylose, and glucose as whole-cell sugars, menaquinone $10\left(\mathrm{H}_{4}\right)$, and glycolyl cell wall polysaccharides and has a guanine-plus-cytosine content of $69.0 \mathrm{~mol} \%$. Mycolic acids are absent. Phosphatidylinositol and phosphatidylethanolamine are diagnostic phospholipids. The chemotaxonomic data, except for the lack of arabinose in the whole-cell sugars, indicate that this strain belongs to the family Micromonosporaceae. The morphological and physiological characteristics and chemotaxonomic and phylogenetic data for this strain differ from those of the previously described actinomycetes. We therefore propose a new genus, Spirilliplanes, for this organism; the type species of the genus is Spirilliplanes yamanashiensis sp. nov., and the type strain of S. yamanashiensis is strain YU127-1 (= IFO 15828).
\end{abstract}

The family Micromonosporaceae was emended by Goodfellow et al. (5) to include the chemotaxonomically defined actinomycete group whose members are cell wall chemotype II and whole-cell sugar pattern D organisms (14). At that time, this family included the genera Micromonospora, Actinoplanes, Dactylosporangium, and Pilimelia. The genera Catellatospora (2) and Glycomyces (12) also have these properties. Furthermore, it was suggested that the genera Catenuloplanes and Couchioplanes, which are cell wall type VI and whole-cell sugar pattern $\mathrm{D}$ taxa or have xylose as the sole diagnostic sugar $(25$, 28 ), should be included in this family based on a phylogenetic study in which $16 \mathrm{~S}$ rRNA sequences were used (25).

During our taxonomic studies of motile actinomycetes, we isolated strain YU127-1 ${ }^{\mathrm{T}}$ ( $\mathrm{T}=$ type strain) from a soil sample from Yamanashi Prefecture, Japan. This organism produces zoospores and has meso-diaminopimelic acid and glycine in its cell wall (chemotype II). Among the actinomycete genera with chemotype II walls, the genera Micromonospora, Catellatospora, and Glycomyces do not produce zoospores, and the genera Actinoplanes, Dactylosporangium, and Pilimelia are known to form motile sporangiospores. The following five genera that form zoospores in chains have been described previously: Sporichthya (15), Actinosynnema (7), Actinokineospora (6), Catenuloplanes, and Couchioplanes. However, the genus Sporichthya is a wall chemotype I taxon, the genus Actinosynnema is a wall chemotype III taxon, the genus Actinokineospora is a wall chemotype IV taxon, and the genera Catenuloplanes and Couchioplanes are wall chemotype VI taxa. Therefore, strain YU127-1 $1^{\mathrm{T}}$ differs from the previously described members of chemotype II genera and the actinomycete genera which produce zoospores in chains.

In this paper we describe the characterization and classification of strain YU127-1 ${ }^{\mathrm{T}}$, and we propose that this organism should be included in a new genus, the genus Spirilliplanes, and a new species, Spirilliplanes yamanashiensis.

* Corresponding author. Mailing address: Institute for Fermentation, Osaka, 17-85, Juso-honmachi 2-chome, Yodogawa-ku, Osaka 532, Japan. Phone: 81-06-300-6555. Fax: 81-06-300-6814. E-mail: k90089 @sinet.ad.jp.

\section{MATERIALS AND METHODS}

Microorganisms and culture conditions. Strain YU127-1 ${ }^{\mathrm{T}}$ was isolated from a soil sample that was collected at Kofu in Yamanashi Prefecture, Japan, treated by dry heating $\left(120^{\circ} \mathrm{C}, 1 \mathrm{~h}\right)(18)$, suspended in sterile water, and spread onto humic acid-vitamin (HV) agar (8). Mycobacterium smegmatis was used for a comparison of cell wall sugar compositions. To obtain freeze-dried cells for chemotaxonomic analyses, a culture was grown in yeast extract-glucose broth (containing $10 \mathrm{~g}$ of yeast extract and $10 \mathrm{~g}$ of D-glucose in $1,000 \mathrm{ml}$ of distilled water; $\mathrm{pH} 7.0$ ) on a rotary shaker at $28^{\circ} \mathrm{C}$. Strain YU127-1 ${ }^{\mathrm{T}}$ has been deposited in the Institute for Fermentation, Osaka culture collection as strain IFO $15828^{\mathrm{T}}$.

Cultural characteristics were determined after 14 days of incubation at $28^{\circ} \mathrm{C}$ by International Streptomyces Project (ISP) methods (24). Colors are described below in common terms, but exact colors were determined by comparison with color chips in A Mycological Colour Chart (20).

Morphological and physiological characterization. Morphological features were observed on HV agar, and physiological features were observed on media commonly used for characterization of Streptomyces species (24). Motility was studied with a light microscope by using spores grown on HV agar for 7 to 10 days at $28^{\circ} \mathrm{C}$ and then incubated at $28^{\circ} \mathrm{C}$ for $1 \mathrm{~h}$ in distilled water or $0.01 \mathrm{M}$ phosphate buffer ( $\mathrm{pH} \mathrm{7.0)}$ containing $10 \%$ soil extract. Colonies grown on HV agar for 14 days at $28^{\circ} \mathrm{C}$ were investigated with a scanning electron microscope (model JSM-5400; JEOL, Ltd., Tokyo, Japan). Samples for scanning electron microscopy were prepared by cutting a block from an agar plate, fixing it in $2 \%$ osmium tetroxide vapor at room temperature for $4 \mathrm{~h}$, dehydrating it through a graded ethanol series, substituting isoamyl acetate for ethanol, critical point drying (model HCP-2 apparatus; Hitachi Koki Co., Ltd., Tokyo, Japan), and then sputter coating with palladium under a vacuum.

Analyses of chemotaxonomic characteristics. The glycolate test and analyses of whole-cell sugars, polar lipids, cellular fatty acids, mycolic acids, isoprenoid quinones, peptidoglycan, and DNA base composition were performed as described previously (25).

To identify an unknown sugar in the whole cells of strain YU127-1 ${ }^{\mathrm{T}}$, a sample was prepared as follows. Dried whole cells were hydrolyzed with $2 \mathrm{~N} \mathrm{HCl}$ as previously described (25). The hydrolysate was reduced with sodium borohydride in $\mathrm{D}_{2} \mathrm{O}$ to make the ${ }^{2} \mathrm{H}$-labeled alditols, which were acethylated by the method of Albersheim et al. (1). The products were analyzed with a model GC-17A gas chromatograph (Shimadzu, Kyoto, Japan) equipped with a type Rtx-2330 column ( $30 \mathrm{~m}$ by $0.25 \mathrm{~mm}$; Restek Co., Bellefonte, Pa.) and a Shimadzu model QP-5000 mass spectrofluorometer.

PCR and sequencing of the products. 16S rRNA was amplified by PCR (21) by using TaKaRa Taq (Takara Shuzo, Kyoto, Japan) and primers 9F (5'-GAGTT TGATCCTGGCTCAG) and 1541R (5'-AAGGAGGTGATCCAACC). The conditions used for thermal cycling were as follows: denaturation of the target DNA at $95^{\circ} \mathrm{C}$ for $1 \mathrm{~min}$, followed by 30 cycles consisting of denaturation at $95^{\circ} \mathrm{C}$ for $1 \mathrm{~min}$, primer annealing at $50^{\circ} \mathrm{C}$ for $1 \mathrm{~min}$, and primer extension at $72^{\circ} \mathrm{C}$ for $1.5 \mathrm{~min}$. At the end of the cycle, the reaction mixture was kept at $72^{\circ} \mathrm{C}$ for $5 \mathrm{~min}$ and then cooled to $4^{\circ} \mathrm{C}$. The 1.5 -kb amplified 16S ribosomal DNA (rDNA) fragment was separated by agarose gel electrophoresis and purified by using a Prep-A-Gene DNA purification kit (Bio-Rad Laboratories, Hercules, Calif.). 
TABLE 1. Strains investigated in this study and 16S rDNA accession numbers

\begin{tabular}{|c|c|c|}
\hline Taxon & Strain & $\begin{array}{c}\text { Accession } \\
\text { no. }\end{array}$ \\
\hline Spirilliplanes yamanashiensis & $\begin{array}{l}\text { YU127-1 } \\
\qquad\left(=\text { IFO } 15828^{\mathrm{T}}\right)\end{array}$ & D63912 \\
\hline Actinobispora yunnanensis & IFO 15681 & D85472 \\
\hline Actinocorallia herbida & IFO 15485 & D85473 \\
\hline Actinomadura madurae & IFO 14623 & D85468 \\
\hline Actinomadura viridis & IFO 15238 & $\mathrm{D} 85467^{a}$ \\
\hline Actinoplanes philippinensis & IFO 13878 & $\mathrm{D} 85474^{a}$ \\
\hline Actinosynnema mirum & IFO 14064 & D85475 \\
\hline Amycolatopsis orientalis subsp. orientalis & IFO 12806 & D86935 \\
\hline Catellatospora citrea subsp. citrea & IFO 14495 & D85477 \\
\hline Catenuloplanes japonicus & IFO 14176 & D85476 \\
\hline Couchioplanes caeruleus subsp. azureus & IFO 13993 & D85478 \\
\hline Couchioplanes caeruleus subsp. caeruleus & IFO 13939 & D85479 \\
\hline Dactylosporangium aurantiacum & IFO 12592 & D $85480^{a}$ \\
\hline Dactylosporangium fulvum & IFO 14381 & $\mathrm{D} 86942^{a}$ \\
\hline Dactylosporangium matsuzakiense & IFO 14259 & $\mathrm{D} 86940^{a}$ \\
\hline Dactylosporangium roseum & IFO 14352 & $\mathrm{D} 86941^{a}$ \\
\hline Dactylosporangium salmoneum & IFO 14103 & D86938 \\
\hline Dactylosporangium thailandense & IFO 12593 & $\mathrm{D} 85481^{a}$ \\
\hline Dactylosporangium vinaceum & IFO 14181 & $\mathrm{D} 86939^{a}$ \\
\hline Excellospora viridilutea & IFO 14480 & $\mathrm{D} 86943^{a}$ \\
\hline Glycomyces harbinensis & IFO 14487 & $\mathrm{D} 85483^{a}$ \\
\hline Glycomyces rutgersensis & IFO 14488 & $\mathrm{D} 85484^{a}$ \\
\hline Glycomyces tenuis & IFO 15904 & D $85482^{a}$ \\
\hline Herbidospora cretacea & IFO 15474 & D85485 \\
\hline Intrasporangium calvum & IFO 12989 & D85486 \\
\hline Luteococcus japonicus & IFO 12422 & D85487 \\
\hline Microbispora rosea subsp. rosea & IFO 14044 & $\mathrm{D} 86936^{a}$ \\
\hline Micromonospora chalcea & IFO 12135 & D85489 \\
\hline Microtetraspora glauca & IFO 14761 & $\mathrm{D} 85490^{a}$ \\
\hline Microtetraspora pusilla & IFO 14684 & D $85491^{a}$ \\
\hline Nocardiopsis dassonvillei & IFO 14626 & $\mathrm{D} 85492^{a}$ \\
\hline Pilimelia terevasa & IFO 15964 & $\mathrm{D} 86946^{a}$ \\
\hline Planobispora longispora & IFO 13918 & $\mathrm{D} 85494^{a}$ \\
\hline Planomonospora parontospora & IFO 13880 & $\mathrm{D} 85495^{a}$ \\
\hline Planotetraspora mira & IFO 15435 & D85496 \\
\hline Spirillospora albida & IFO 12248 & D85498 \\
\hline Streptoalloteichus hindustanus & IFO 15115 & D85497 \\
\hline Streptosporangium album & IFO 13900 & D85469 \\
\hline Thermomonospora curvata & IFO 15933 & D86945 \\
\hline
\end{tabular}

${ }^{a}$ Data from direct sequencing.

The purified fragment was blunt ended with T4 DNA polymerase by using a DNA blunting kit (Takara Shuzo), and the 5' end of the amplified DNA was phosphorylated with T4 polynucleotide kinase (Takara Shuzo) according to the manufacturer's instructions. The DNA was ligated into the dephosphorylated $H$ HincII site of phagemid vector pUC118 (Takara Shuzo). The phagemid was introduced into Escherichia coli JM109 (27). Single-stranded DNA for use as a sequencing template was obtained after infection with bacteriophage M13KO7 (26). Plasmids were prepared by the Miniprep protocol (16).

The single-stranded DNA and plasmid-cloned material were sequenced by using an AutoRead sequencing kit (Pharmacia, Uppsala, Sweden) and were analyzed with a Pharmacia model A.L.F. DNA Sequencer II apparatus. The 5 '-fluorescein-labeled oligonucleotide primers used were M13 Universal and Reverse primer (Pharmacia) and primer 1111R (5'-TTGCGCTCGTTGCGGG ACT).

Phylogenetic analysis. The $16 \mathrm{~S}$ rRNA sequences of the strains examined (Table 1) and the sequences of reference organisms obtained from databases were aligned with the sequence of Streptomyces ambofaciens (19). Evolutionary distances were represented by the $K_{\text {nuc }}$ value of Kimura (9), and a phylogenetic tree was constructed by the neighbor-joining method (22) from $K_{\text {nuc }}$ values. The topology of the phylogenetic tree was evaluated by the bootstrap resampling method of Felsenstein (4) with 1,000 replicates.

Nucleotide sequence accession numbers. The nucleotide sequence data reported in this paper have been deposited in the DDBJ, EMBL, and GenBank nucleotide sequence databases, under the accession numbers shown in Table 1.

\section{RESULTS}

Morphological observations. Morphological observation of a 14-day-old culture of strain YU127-1 ${ }^{\mathrm{T}}$ grown on $\mathrm{HV}$ agar revealed the presence of short hyphae arranged in spirals, which could arise from the substrate mycelia. The aerial mycelium at maturity formed short chains of spores (Fig. 1B through D). Although the sporogenous hyphae aggregated into clusters resembling sporangia (Fig. 1A), no true sporangia were observed, because the hyphae were not covered with a sheath (Fig. 1B through D). Several spores per sporogenous hypha were observed, and the spores were ovals to short rods $(0.5$ to 0.7 by 0.7 to $1.0 \mu \mathrm{m}$ ) with smooth surfaces (Fig. 1$)$.

After incubation at $28^{\circ} \mathrm{C}$ for $1 \mathrm{~h}$ in both water and $0.01 \mathrm{M}$ phosphate buffer ( $\mathrm{pH} 7.0$ ) containing $10 \%$ soil extract, spores showed active motility. More zoospores were observed when phosphate buffer was used than when water was used.

Growth characteristics. As shown in Table 2, strain YU127-1 $1^{\mathrm{T}}$ developed yellow to orange colonies on most media tested. It showed good growth on oatmeal agar (ISP medium 3 ), inorganic salts-starch agar (ISP medium 4), and peptoneyeast extract-iron agar (ISP medium 6), and it produced a brown soluble pigment on tyrosine agar (ISP medium 7). It developed aerial hyphae on most media tested, especially inorganic salts-starch agar (ISP medium 4) and HV agar (Fig. 1).

Physiological and biochemical characteristics. The biochemical properties of strain YU127-1 ${ }^{\mathrm{T}}$ are shown in Table 3. The strain utilized glucose, rhamnose, and mannitol. It was positive for gelatin liquefaction and hydrolysis of starch and negative for decomposition of calcium malate, reduction of nitrate, and peptonization of milk.

Chemotaxonomic characteristics. The menaquinone composition, cell wall amino acid composition, whole-cell sugar pattern, phospholipid type, and DNA guanine-plus-cytosine $(\mathrm{G}+\mathrm{C})$ content of strain YU127-1 ${ }^{\mathrm{T}}$ are shown in Table 4 . The major menaquinone was $\mathrm{MK}-10\left(\mathrm{H}_{4}\right)$, and small amounts of MK-10 $\left(\mathrm{H}_{6}\right)$ and MK-10 $\left(\mathrm{H}_{8}\right)$ were also present. The cell walls contained meso-diaminopimelic acid, glucosamine, glycine, glutamic acid, and alanine, indicating that the strain is a wall chemotype II strain according to the scheme of Lechevalier and Lechevalier (14), and the peptidoglycan type was type A1 $\gamma$ according to the classification of Schleifer and Kandler (23). Whole cells of strain YU127-1 ${ }^{\mathrm{T}}$ contained large amounts of mannose, glucose, and an unknown sugar and small amounts of galactose and xylose. Arabinose and rhamnose were not detected. The unknown sugar was identified as 3-O-methylmannose by an analysis of the fragment pattern after a gas chromatography-mass spectrometry analysis and comparison of the retention time with the retention time of Mycobacterium smegmatis (17) during high-performance liquid chromatography. Phosphatidylethanolamine and phosphatidylinositol were diagnostic phospholipids, and phosphatidylglycerol, phosphatidylcholine, and an unidentified phospholipid including glucosamine were not detected. This pattern corresponds to phospholipid type II (13). The $\mathrm{G}+\mathrm{C}$ content of DNA was 69.0 mol\%. The fatty acids are shown in Table 5. The major cellular fatty acids detected were $C_{17: 1}, C_{17: 0}$, anteiso- $C_{15: 0}$, iso- $C_{15: 0}$, and iso- $\mathrm{C}_{16: 0}$, which corresponds to fatty acid type $2 \mathrm{~d}(11)$. The acyl type of the cell wall polysaccharides was glycolyl. Mycolic acid was absent.

Phylogenetic position. The sequencing strategy generated a continuous sequence ranging from position 10 to position 1541 (E. coli numbering system [3]). The total number of nucleotides compared was 1,173 after elimination of all sites whose nucleotides were not determined in any sequence. The phylogenetic tree obtained by applying the neighbor-joining method 


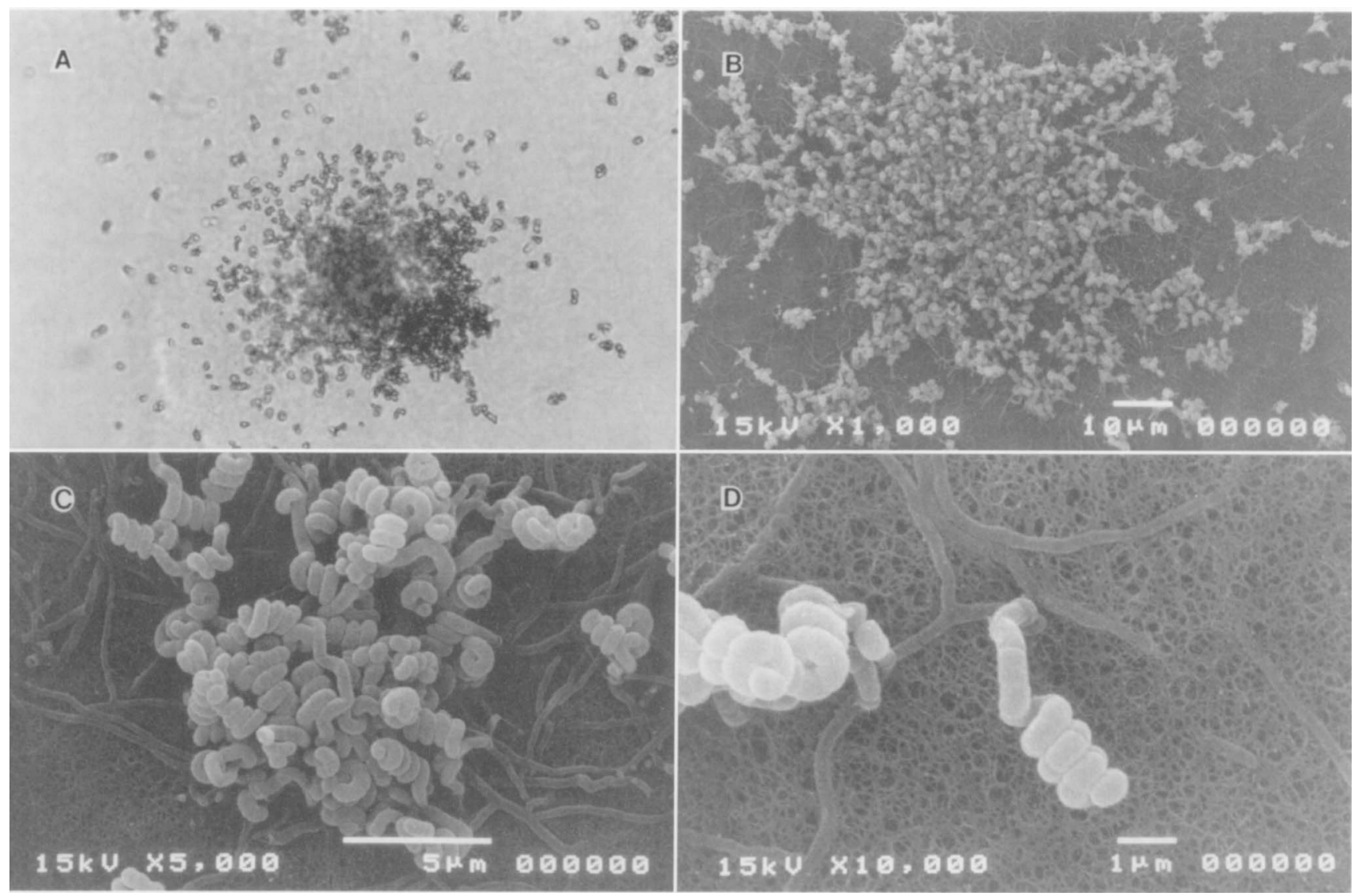

FIG. 1. Light micrograph (A) and scanning electron micrographs (B through D) of $S$. yamanashiensis $\mathrm{YU}^{2} 1271^{\mathrm{T}}$ grown on $\mathrm{HV}$ agar for 14 days at $28^{\circ} \mathrm{C}$.

to $K_{\text {nuc }}$ values is shown in Fig. 2. 16S rDNA analysis revealed that YU127-1 $1^{\mathbf{T}}$ is phylogenetically related to members of the genera Micromonospora, Actinoplanes, Dactylosporangium, Pilimelia, Catellatospora, Catenuloplanes, and Couchioplanes (similarity levels, 95.9 to $97.6 \%$ ). These strains phylogenetically form a cluster, and this cluster is distinct from other groups, such as the families Streptosporangiaceae, Pseudonocardiaceae, etc. The bootstrap analysis gave a relatively high level $(99 \%)$ for the separation of this cluster from other groups, so the branching order in this region is definite. The genus Glycomyces is phylogenetically independent; it is clearly less closely related to members of the family Micromonosporaceae (similarity levels, 87.4 to $89.8 \%$ ) and other actinomycetes (similarity levels, 87.4 to $85.5 \%$ ).

\section{DISCUSSION}

Strain YU127-1 $1^{\mathrm{T}}$ is a wall chemotype II organism. The chains of very narrow and coiled sporogenous hyphae with zoospores often appear to be sporangium-like structures under a light microscope. Under a scanning electron microscope, however, these structures are found to be aggregated hyphae, not true sporangia.

The genera Micromonospora, Actinoplanes, Dactylosporan-

TABLE 2. Cultural characteristics of strain YU127-1 ${ }^{\mathrm{T}}$

\begin{tabular}{|c|c|c|c|c|}
\hline Medium & Growth & Sporulation & Diffusible pigment $^{a}$ & Color of colony ${ }^{a}$ \\
\hline $\begin{array}{l}\text { Yeast extract-malt extract agar } \\
\text { (ISP medium 2) }\end{array}$ & Moderate & Moderate & Absent & Strong orange (7) \\
\hline Oatmeal agar (ISP medium 3) & Good & Moderate & Absent & Light to moderate orange-yellow (10) \\
\hline $\begin{array}{l}\text { Inorganic salts-starch agar } \\
\quad \text { (ISP medium 4) }\end{array}$ & Good & Good & Absent & $\begin{array}{l}\text { Light to moderate orange-yellow (10) to } \\
\text { strong orange }(7)\end{array}$ \\
\hline $\begin{array}{l}\text { Glycerol-asparagine agar } \\
\text { (ISP medium 5) }\end{array}$ & Moderate & Poor & Absent & Light to moderate orange-yellow (10) \\
\hline $\begin{array}{l}\text { Peptone-yeast extract-iron agar } \\
\text { (ISP medium 6) }\end{array}$ & Good & Poor & Absent & $\begin{array}{l}\text { Moderate orange-yellow (44) to vivid } \\
\text { yellow (12) }\end{array}$ \\
\hline Tyrosine agar (ISP medium 7) & Moderate & Poor to moderate & Moderate brown (63) & $\begin{array}{l}\text { Moderate reddish brown }(60) \text { to moder- } \\
\text { ate orange }(62)\end{array}$ \\
\hline Nutrient agar & Moderate & Absent & Absent & Moderate orange $(42)$ \\
\hline
\end{tabular}

${ }^{a}$ The color codes in parentheses correspond to the color codes in A Mycological Colour Chart (20). 
TABLE 3. Phenotypic characteristics of strain YU127-1 ${ }^{\mathrm{T}}$

\begin{tabular}{|c|c|}
\hline Characteristic & $\begin{array}{l}\text { Strain YU127-1 } \\
\text { reaction }\end{array}$ \\
\hline \multicolumn{2}{|l|}{ Utilization of: } \\
\hline \multicolumn{2}{|l|}{ Glucose ........... } \\
\hline \multicolumn{2}{|c|}{ 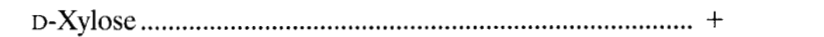 } \\
\hline \multicolumn{2}{|c|}{ 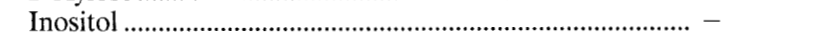 } \\
\hline \multicolumn{2}{|c|}{ Saccharose ……1. } \\
\hline \multicolumn{2}{|c|}{ Raffinose } \\
\hline \multicolumn{2}{|c|}{ 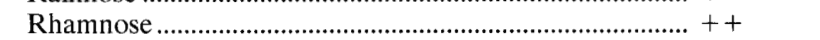 } \\
\hline \multicolumn{2}{|c|}{ D-Mannitol . } \\
\hline \multicolumn{2}{|c|}{ 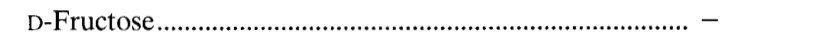 } \\
\hline \multicolumn{2}{|c|}{ 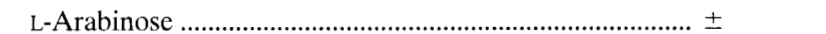 } \\
\hline \multicolumn{2}{|c|}{ Pigmentation in: } \\
\hline \multicolumn{2}{|c|}{ ISP medium 1 } \\
\hline \multicolumn{2}{|c|}{ ISP medium 6} \\
\hline \multicolumn{2}{|c|}{ 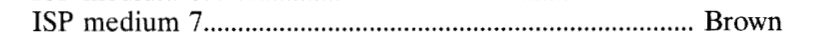 } \\
\hline \multicolumn{2}{|c|}{ Gelatin liquefaction } \\
\hline \multicolumn{2}{|c|}{ Peptonization of milk } \\
\hline \multicolumn{2}{|c|}{ Starch hydrolysis } \\
\hline \multicolumn{2}{|c|}{ 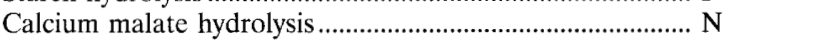 } \\
\hline \multicolumn{2}{|c|}{ 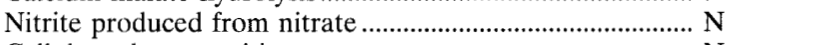 } \\
\hline Cellulose decomposit & ........ N \\
\hline
\end{tabular}

${ }^{a}++$, good; + , moderate; \pm , poor; - , none; $\mathrm{P}$, positive; $\mathrm{N}$, negative.

gium, Pilimelia, Glycomyces, and Catellatospora are wall chemotype II taxa. Among the wall chemotype II genera, the genera Actinoplanes, Dactylosporangium, and Pilimelia have motile elements. However, YU127-1 ${ }^{\mathrm{T}}$ is distinguishable from these genera in that its spores are not enclosed in a sporangial wall and arabinose is not a whole-cell sugar. Strain YU127-1 ${ }^{\mathrm{T}}$ can also be distinguished from the genera Dactylosporangium and Pilimelia by its menaquinone pattern. We previously reported that the genera Catenuloplanes and Couchioplanes phylogenetically belong to the family Micromonosporaceae (25). YU127-1 ${ }^{\mathrm{T}}$ resembles these genera in that all of these taxa have sporogenous hyphae with zoospores. However, it differs from them in wall chemotype and in menaquinone and cellular fatty acid contents (Table 6).

On the basis of morphological, physiological, chemotaxonomic, and phylogenetic criteria, strain YU127-1 ${ }^{\mathbf{T}}$ is readily distinguishable from the motile actinomycetes mentioned above and warrants a new taxon. Therefore, we propose that strain YU127-1 ${ }^{\mathrm{T}}$ (= IFO $15828^{\mathrm{T}}$ ) be classified in a new genus, the genus Spirilliplanes, whose the type species is Spirilliplanes yamanashiensis $\mathrm{sp}$. nov.

The genus Spirilliplanes should be considered a member of the family Micromonosporaceae Krassilnikov 1938 emend. Goodfellow et al. 1990 (5) on the basis of the results of the comparative analysis of $16 \mathrm{~S}$ rRNA sequences described here. Furthermore, the genus Catellatospora, which is a wall chemotype II taxon, should also be placed in this family on the basis of the results of the comparative analysis of $16 \mathrm{~S}$ rRNA sequences described here. Goodfellow et al. (5) described the criteria for members of the family Micromonosporaceae as follows. The wall peptidoglycan of members of the family Micromonosporaceae contains meso- and/or 3-hydroxy-diaminopimelic acid and is a type A1 $\gamma$, peptidoglycan, and whole-cell hydrolysates are rich in arabinose and xylose and contain variable amounts of other sugars (5). However, the genus Spirilliplanes contains no detectable arabinose in its whole-cell sugars, and the genus Catenuloplanes contains small amounts of arabinose or no arabinose (28). Furthermore, the genus Spirilliplanes contains 3-O-methyl-mannose as a characteristic sugar. The genera Catenuloplanes and Couchioplanes, while phyloge-
TABLE 4. Chemotaxonomic characteristics of strain YU127-1 ${ }^{\mathrm{T}}$

\begin{tabular}{|c|c|}
\hline Characteristic & $\begin{array}{l}\text { Strain } \\
\text { YU127-1 }\end{array}$ \\
\hline \multicolumn{2}{|l|}{ Major menaquinones ${ }^{a}$} \\
\hline MK-10 $\left(\mathrm{H}_{4}\right) \ldots \ldots \ldots \ldots \ldots \ldots \ldots \ldots \ldots \ldots \ldots \ldots \ldots$ & ++ \\
\hline MK-10 $\left(\mathrm{H}_{6}\right)$ & + \\
\hline MK-10 $\left(\mathrm{H}_{8}\right)$ & + \\
\hline \multicolumn{2}{|l|}{$\begin{array}{l}\text { Amino acid composition of peptidoglycan } \\
\text { (molar ratio) })^{b}\end{array}$} \\
\hline Glutamic acid & 1.00 \\
\hline 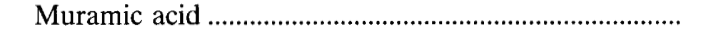 & 0.43 \\
\hline 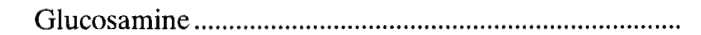 & 0.84 \\
\hline Glycine & 1.43 \\
\hline 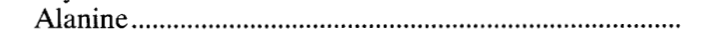 & 0.79 \\
\hline 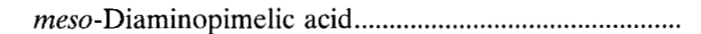 & 1.05 \\
\hline \multicolumn{2}{|l|}{ Sugar composition of whole cells ${ }^{c}$} \\
\hline 3-O-Methylmannose & + \\
\hline 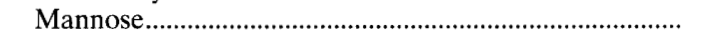 & + \\
\hline Arabinose & - \\
\hline Galactose & + \\
\hline 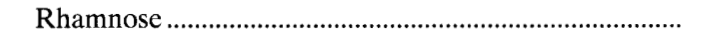 & - \\
\hline Xylose & + \\
\hline 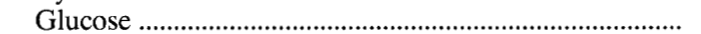 & + \\
\hline \multicolumn{2}{|l|}{ Phospholipid composition ${ }^{c}$} \\
\hline Phosphatidylinositol & + \\
\hline 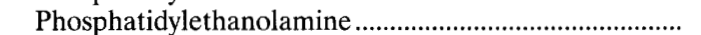 & + \\
\hline Phosphatidylcholine & - \\
\hline Phosphatidylglycerol & - \\
\hline Unidentified phospholipid including & \\
\hline $\begin{array}{l}\text { glucosamine } \\
\text { Glycolyl test }\end{array}$ & \\
\hline $\mathrm{G}+\mathrm{C}$ content of DNA $(\mathrm{mol} \%)$ & 69.0 \\
\hline
\end{tabular}

${ }^{b}$ Calculated by defining the amount of glutamic acid as 1.00 .

$c+$, present; - , absent.

netically belonging to the family Micromonosporaceae, have L-lysine instead of meso-diaminopimelic acid in their wall peptidoglycan and their peptidoglycan type is type $\mathrm{A} 3 \gamma(25,28)$. Thus, the diamino acid in the cell wall and the presence of arabinose in the whole-cell sugars are not important criteria for membership in the family Micromonosporaceae. It is thought that the criteria for membership in the family Micro-

TABLE 5. Cellular fatty acid composition of strain YU127-1 ${ }^{\mathrm{T}}$

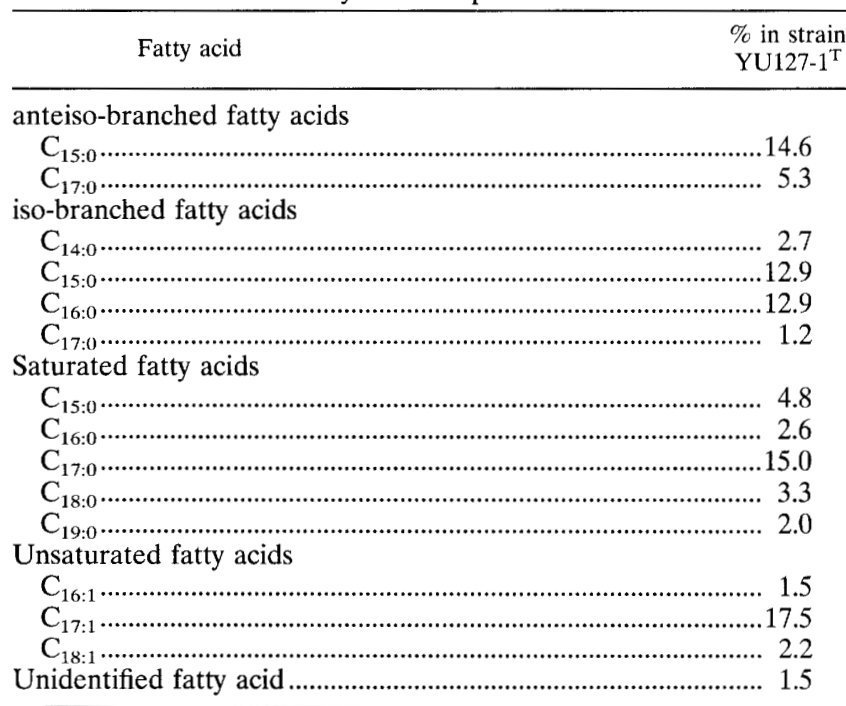




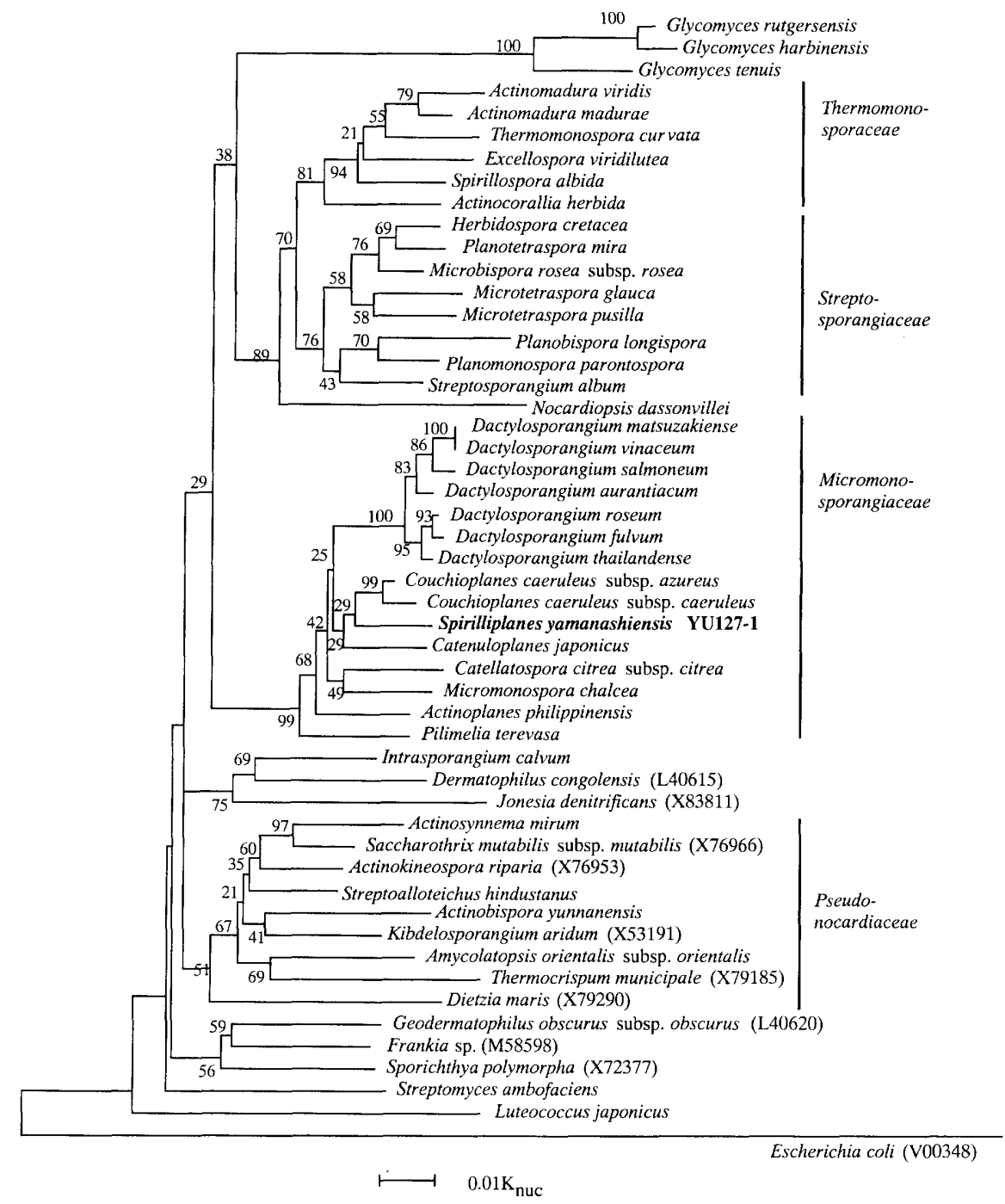

FIG. 2. Phylogenetic tree derived from $16 \mathrm{~S}$ rRNA sequences of actinomycetes. $E$. coli was used as the root organism. Scale bar $=0.01 K_{\text {nuc }}$ in nucleotide sequences. The numbers on the branches are confidence limits (expressed as percentages) estimated from a bootstrap analysis with 1,000 replicates.

monosporaceae include the presence of meso- and/or 3-hydroxy-diaminopimelic acid or L-lysine in the wall peptidoglycan and the presence of xylose in whole cells, while the presence of arabinose in the whole cells is variable (sugar pattern $D$ or xylose is the sole diagnostic sugar) (14).

The genus Glycomyces, a wall chemotype II taxon, should not be placed in this family on the basis of the comparative analysis of $16 \mathrm{~S}$ rRNA sequences described here. Further study will be necessary to determine the position of the genus Glycomyces.

The family Micromonosporaceae was recently emended by Koch et al. (10), and thus we could not address that issue.

Description of Spirilliplanes gen. nov. Spirilliplanes (Spi.ril. li.plan'es. Gr. n. speira, coil; Gr. n. planes, a wanderer; M.L. fem.n. Spirilliplanes, an organism with wandering cells, in spirals). Gram-positive, non-acid-fast, aerobic organisms with branching hyphae. Nonfragmenting substrate mycelia are present. The aerial hyphae aggregate into clusters resembling coils, but true sporangia are not observed; 14-day-old cultures grown on inorganic salts-starch agar have hyphae arranged in spirals of 5 to 10 turns with several spores per spore chain. Spores are ovals or short rods ( 0.5 to 0.7 by 0.7 to $1.0 \mu \mathrm{m})$ with smooth surfaces and are motile when they are suspended in $0.01 \mathrm{M}$ phosphate buffer ( $\mathrm{pH} \mathrm{7.0)}$ containing $10 \%$ soil extract or distilled water.

Strictly aerobic. Good growth occurs at temperatures between 25 and $30^{\circ} \mathrm{C}$. The organism shows good growth on oatmeal agar, inorganic salts-starch agar, and peptone-yeast extract-iron agar. In general, the vegetative mycelia of the strain are yellow to orange, and aerial hyphae are white.

Cell walls contain glutamic acid, glucosamine, glycine, alanine, and meso-diaminopimelic acid. The wall chemotype is type II according to the scheme of Lechevalier and Lechevalier (14), and the peptidoglycan type is presumed to be type A1 $\gamma$ according to the classification of Schleifer and Kandler (23). Mannose, 3- $O$-methylmannose, glucose, xylose, and galactose are detected in the whole-cell sugars. $\mathrm{C}_{17: 1}, \mathrm{C}_{17: 0}$, anteiso- $\mathrm{C}_{15: 0}$, iso- $\mathrm{C}_{15: 0}$, and iso- $\mathrm{C}_{16: 0}$ are present as major cellular fatty acids. The $\mathrm{G}+\mathrm{C}$ content of the DNA is $69 \mathrm{~mol} \%$. The major menaquinone is MK-10 $\left(\mathrm{H}_{4}\right)$, and small amounts of $\mathrm{MK}-10\left(\mathrm{H}_{6}\right)$ and MK-10 $\left(\mathrm{H}_{8}\right)$ are also present. Phosphatidylethanolamine and phosphatidylinositol are diagnostic phospholipids (phospho- 
TABLE 6. Differential characteristics of the genus Spirilliplanes and related genera ${ }^{a}$

\begin{tabular}{|c|c|c|c|c|c|c|c|c|c|}
\hline Genus & $\begin{array}{c}G+C \text { content } \\
\text { of DNA } \\
(\mathrm{mol} \%)\end{array}$ & $\begin{array}{l}\text { Motility } \\
\text { of spores }\end{array}$ & $\begin{array}{l}\text { Sporangium } \\
\text { formation }\end{array}$ & $\begin{array}{c}\text { Glycolyl } \\
\text { test }\end{array}$ & $\begin{array}{l}\text { Fatty acid } \\
\text { type }^{b}\end{array}$ & $\begin{array}{l}\text { Cell wall } \\
\text { type }^{c}\end{array}$ & Major menaquinone(s) & $\begin{array}{l}\text { Phospholipid } \\
\text { type }^{d}\end{array}$ & $\begin{array}{c}\text { Characteristic } \\
\text { sugar(s) in } \\
\text { whole cells }\end{array}$ \\
\hline Spirilliplanes & 69 & + & - & Glycolyl & $2 d$ & II & MK-10( $\left.\mathrm{H}_{4}\right)$ & PII & Xyl, Gal \\
\hline Actinoplanes & $72-73$ & + & + & Glycolyl & $2 d$ & II & MK-9 $\left(\mathrm{H}_{4}\right)$, MK-10( $\left.\mathrm{H}_{4}\right)$ & PII & Ara, Xyl \\
\hline Dactylosporangium & $72-73$ & + & + & Glycolyl & $3 b$ & II & MK-9 $\left(\mathrm{H}_{4}, \mathrm{H}_{6}, \mathrm{H}_{8}\right)$ & PII & Ara, Xyl \\
\hline Pilimelia & ND & + & + & Glycolyl & $2 \mathrm{~d}$ & II & MK-9 $\left(\mathrm{H}_{2}, \mathrm{H}_{4}\right)$ & PII & Ara, Xyl \\
\hline Micromonospora & $71-73$ & - & - & Glycolyl & $3 b$ & II & MK-10 $\left(\mathbf{H}_{4}, \mathbf{H}_{6}\right)$, MK-9 $\left(\mathbf{H}_{4}, \mathbf{H}_{6}\right)$ & PII & Ara, Xyl \\
\hline Catenuloplanes & $71-73$ & + & - & Glycolyl & $2 \mathrm{c}$ & VI & MK-9 $\left(\mathrm{H}_{8}\right)$, MK-10 $\left(\mathrm{H}_{8}\right)$ & PIII & Xyl \\
\hline Couchioplanes & $70-72$ & + & - & Glycolyl & $2 \mathrm{c}$ & VI & MK-9 $\left(\mathrm{H}_{4}\right)$ & PII & Xyl, Ara, Gal \\
\hline Catellatospora & $71-72$ & - & - & Glycolyl & ND & II & MK-10 $\left(\mathrm{H}_{8}, \mathrm{H}_{6}\right)$, MK-9 $\left(\mathrm{H}_{4}, \mathrm{H}_{6}\right)$ & PII & Ara, Xyl \\
\hline Glycomyces & $71-73$ & - & - & Glycolyl & $2 \mathrm{c}$ & II & MK-9 $\left(\mathrm{H}_{4}\right)$, MK-10( $\left.\mathrm{H}_{2}, \mathrm{H}_{4}\right)$ & PI & Ara, Xyl \\
\hline
\end{tabular}

${ }^{a}+$, present; -, absent; ND, not determined.

${ }^{b}$ According to the classification of Kroppenstedt (11).

${ }^{c}$ According to the classification of Lechevalier and Lechevalier (14).

${ }^{d}$ According to the classification of Lechevalier et al. (13).

e Xyl, xylose; Gal, galactose; Ara, arabinose.

lipid pattern type PII). The acyl type of the cell wall polysaccharides is glycolyl. Habitat: soil.

The type species is Spirilliplanes yamanashiensis.

Description of Spirilliplanes yamanashiensis sp. nov. Spirilliplanes yamanashiensis (ya.ma.na.shi.en'sis. M.L. adj. yamanashiensis, pertaining to Yamanashi Prefecture, Japan, the source of soil from which the organism was isolated.) The morphological, chemotaxonomic, and general characteristics are the same as those given above for the genus. Brownish soluble pigment is produced on tyrosine agar (ISP medium 7). Gelatin liquefaction positive. Hydrolyzes starch. Does not decompose calcium malate. Does not coagulate milk. Xylose, glucose, inositol, raffinose, rhamnose, mannitol, and sucrose are utilized, but fructose and inositol are not. The $\mathrm{G}+\mathrm{C}$ content of the DNA is $69 \mathrm{~mol} \%$. The type strain is strain IFO 15828.

\section{ACKNOWLEDGMENTS}

This research was supported in part by a grant from the Waksman Foundation of Japan, Inc.

We thank Akira Yokota, Tokyo University, for advice and Mariko Takeuch, Yasuyoshi Nakagawa, and Kumiko Ueda for help with 16S rRNA sequencing.

\section{REFERENCES}

1. Albersheim, P., D. J. Nevins, P. D. English, and A. Kerr. 1967. A method for the analysis of sugars in plant-cell polysaccharides by gas-liquid chromatography. Carbohydr. Res. 5:340-345.

2. Asano, K., and I. Kawamoto. 1986. Catellatospora, a new genus of the Actinomycetales. Int. J. Syst. Bacteriol. 36:512-517.

3. Brosius, J., J. L. Palmer, J. P. Kennedy, and H. F. Noller. 1978. Complete nucleotide sequence of a $16 \mathrm{~S}$ ribosomal RNA gene from Escherichia coli. Proc. Natl. Acad. Sci. USA 75:4801-4805.

4. Felsenstein, J. 1985. Confidence limits on phylogenies: an approach using the bootstrap. Evolution 39:783-791.

5. Goodfellow, M., L. J. Stanton, K. E. Simpson, and D. E. Minnikin. 1990. Numerical and chemical classification of Actinoplanes and some related actinomycetes, J. Gen. Microbiol. 136:19-36.

6. Hasegawa, T. 1988. Actinokineospora: a new genus of the Actinomycetales. Actinomycetologica 2:31-45.

7. Hasegawa, T., M. P. Lechevalier, and H. A. Lechevalier. 1978. New genus of the Actinomycetales: Actinosynnema gen. nov. Int. J. Syst. Bacteriol. 28:304310 .

8. Hayakawa, M., and H. Nonomura. 1987. Humic acid-vitamin agar, a new medium for selective isolation of soil actinomycetes. J. Ferment. Technol. 65:501-509.

9. Kimura, M. 1980. A simple method for estimating evolutionary rates of base substitutions through comparative studies of nucleotide sequences. J. Mol. Evol. 16:111-120.

10. Koch, C., R. M. Kroppenstedt, F. A. Rainey, and E. Stackebrandt. 1996. 16S ribosomal DNA analysis of the genera Micromonospora, Actinoplanes, Ca- tellatospora, Catenuloplanes, Couchioplanes, Dactylosporangium, and Pilimelia and emendation of the family Micromonosporaceae. Int. J. Syst. Bacteriol. 46:765-768.

11. Kroppenstedt, R. M. 1985. Fatty acid and menaquinone analysis of actinomycetes and related organisms, p. 173-199. In M. Goodfellow and D. E. Minnikin (ed.), Chemical methods in bacterial systematics, Academic Press, Ltd., London, United Kingdom.

12. Labeda, D. P., R. T. Testa, M. P. Lechevalier, and H. A. Lechevalier. 1985 Glycomyces, a new genus of the Actinomycetales. Int. J. Syst. Bacteriol. 35:417-421.

13. Lechevalier, M. P., C. DeBievre, and H. A. Lechevalier. 1977. Chemotaxonomy of aerobic actinomycetes: phospholipid composition. Biochem. Syst. Ecol. 5:249-260.

14. Lechevalier, M. P., and H. A. Lechevalier. 1970. Chemical composition as a criterion in the classification of aerobic actinomycetes. Int. J. Syst. Bacteriol. 20:435-443.

15. Lechevalier, M. P., H. A. Lechevalier, and P. E. Holbert. 1968. Sporichthya, un nouveau genre de Streptomycetaceae. Ann. Inst. Pasteur (Paris) 114:277-286.

16. Leonard, G. D., W. M. Kuehl, and J. F. Battey. 1994. Plasmid DNA "Miniprep," p. 245-248. In Basic methods in molecular biology, 2nd ed. Appleton \& Lange, Norwalk, Conn.

17. Maitra, S. K., and C. E. Ballou. 1977 . Heterogeneity and refined structures of 3-O-methyl-D-mannose polysaccharides from Mycobacterium smegmatis. J. Biol. Chem. 252:2459-2469.

18. Nonomura, H., and Y. Ohara. 1969. Distribution of actinomycetes in soil. VI. A culture method effective for both preferential isolation of Microbispora and Streptosporangium strains in soil (part 1). J. Ferment. Technol. 47:463-469.

19. Pernodet, J.-L., F. Borccard, M.-T. Alegre, J. Gargnat, and M. Guérineau. 1989. Organization and nucleotide sequence analysis of ribosomal RNA gene cluster from Streptomyces ambofaciens. Gene 79:33-46.

20. Rayner, R. W. 1970. A mycological colour chart. Commonwealth Mycological Institute, Kew, Surrey \& British Mycological Society, Kew, Surrey, United Kingdom.

21. Saiki, R. K., D. H. Gelfand, S. Stoffe, S. J. Scharf, R. Higuchi, G. T. Horn, K. B. Mullis, and A. Erlich. 1988. Primer-directed enzymatic amplification of DNA with a thermostable DNA polymerase. Science 239:487-491.

22. Saitou, N., and M. Nei. 1987. The neighbor-joining method: a new method for reconstructing phylogenetic trees. Mol. Biol. Evol. 4:406-425.

23. Schleifer, K. H., and O. Kandler. 1972. Peptidoglycan types of bacterial cell walls and their taxonomic implications. Bacteriol. Rev. 36:407-477.

24. Shirling, E. B., and D. Gottlieb. 1966. Methods for characterization of Streptomyces species. Int. J. Syst. Bacteriol. 16:313-340.

25. Tamura, T., Y. Nakagaito, T. Nishii, T. Hasegawa, E. Stackebrandt, and A. Yokota. 1994. A new genus of the order Actinomycetales, Couchioplanes gen. nov., with descriptions of Couchioplanes caeruleus (Horan and Brodsky 1986) comb. nov. and Couchioplanes caeruleus subsp. azureus subsp. nov. Int. J. Syst. Bacteriol. 44:193-203.

26. Vieira, J., and J. Messing. 1987. Production of single-stranded plasmid DNA. Methods Enzymol. 153D:3-11.

27. Yanisch-Perron, C., J. Vieira, and J. Messing. 1985. Improved M13 phage cloning vectors and host strains: nucleotide sequences of the M13mp18 and pUC19 vectors. Gene 33:103-119.

28. Yokota, A., T. Tamura, T. Hasegawa, and L. H. Huang. 1993. Catenuloplanes japonicus gen. nov., sp. nov., nom. rev., a new genus of the order Actinomycetales. Int. J. Syst. Bacteriol. 43:805-812. 